\title{
ANALYSIS OF THE EFFECT OF CREDIT ON PER CAPITA ANNUAL FARM INCOME OF RICE FARMERS; BENEFICIARIES OF SACCO CREDIT IN BENUE STATE NIGERIA
}

\author{
Okolo Samson Ayegba, Olotu Olafemi Ayopo \\ Department of Agribusiness, Federal University of Agriculture, Makurdi.
}

DOI: 10.46609/IJAER.2020.v06i01.008 URL: https://doi.org/10.46609/IJAER.2020.v06i01.008

\begin{abstract}
The analysis of the effect of credit on per capita farm income of beneficiaries of Savings and Credit Cooperative in Benue state, Nigeria is the focus of this work. Random and stratified sampling method was used to select 236 respondents in the study area. Out of the selected respondents only 208 responded and submitted the administered well structured questionnaires correctly. Therefore, the study was based on 208 primary data collected from registered SACCO members in the three Local Government Areas of Benue State. In this study the year 2011 was used for before credit was obtained and 2015 for after credit was obtained. Descriptive statistics, double difference estimator, logistic regression analysis and independent sample t-test were used to achieve the objectives and hypothesis of the study. The result of the double difference estimate showed that the SACCO credit had a positive effect on the per annual farm income of the beneficiaries of the credit with per capita annual farm income of 4719.86 . Sex, education and household size were significant factors that influence participation in SACCO. The sex is significant at $5 \%$ level of significance while education and household size were significant at $1 \%$ level of significance as obtained from the logistic regression analysis. About $77.3 \%$ and $76.2 \%$ of the beneficiaries and non beneficiaries identified and ranked poor access to credit as the major constraint faced by SACCO. Other cardinal constraints were illiteracy level and high cost of farm inputs in the order of severity. SACCO executives and the Government should develop strategies that will bring in more funding, loans and grants to the cooperative consequently enhance availability of credit to members. This will help members who are smallholder farmers to become big estate farm holders. It is also possible that more credit availability to members is a key to poverty reduction due to its positive effect on the increase in per capita annual farm income as seen in the study.
\end{abstract}


International Journal of Agriculture and Environmental Research

ISSN: 2455-6939

Volume: 06, Issue: 01 "January-February 2020"

Keywords: Analysis, annual farm income; rice farmers; constraints; participation; Benue State

\section{INTRODUCTION}

Benue state is known to be a state engaging more than 70 percent of its population in agriculture; agriculture is the back bone of the economy of the state (Ajaero, 2007). The performance in agriculture is relatively average and dwindling due to the poor agricultural finance. The research on the poverty reduction among rice farmers is very important since rice is a major staple in the study area.

Rice is consumed by more than 4.8 billion people in 176 countries and is the most important food crop for over 2.89 billion people in Asia, over 40 million people in Africa and over 150.3 million people in America, (Biyi, 2005). According to Jones, (1995), rice is the second most important cereal in the world after wheat in terms of production; while Nigeria ranks the highest as both producer and consumer of rice in the West Africa sub region. Akande and Akpokodje (2003) opined that, since the mid-1970s, rice consumption in Nigeria has risen tremendously, at about $10 \%$ per annum due to changing preferences while domestic production has never been able to meet the demand leading to considerable imports which today stands at about 1,000,000 metric tons yearly. The imports are procured on the world market with Nigeria spending annually over US $\$ 300$ million on rice imports alone. Similarly, Biyi (2005) observed that the annual domestic output of rice still hovers around 3 million metric tons, leaving the huge gap of about 2 million metric tons annually, a situation, which has continued to encourage dependence on importation. This calls for the need to finance the rice farmers via the umbrella of the savings and credit cooperatives. With adequate financing of the SACCO it is very possible to meet the demand for rice in Nigeria and subsequently reduce poverty from rice farm families.

Therefore, the need for farmers to come together and form an autonomous association of individuals, voluntarily united to meet their common economic, social and cultural needs through a jointly-owned and democratically controlled enterprise (International cooperative alliance, 1996). According to the global Multidimensional Poverty Index, International Monetary Fund (IMF) report by the United Nations (2015) the national average of poverty rate is $46.0 \%$, the national proportion of those living above the poverty line is 54\%. Benue State ranked $24^{\text {th }}$ amongst the states living above the poverty line with $40.8 \%$ above the line and about $59.2 \%$ living below the poverty line.

Savings and credit Cooperatives (SACCO) are important in the provision of financial and banking services to low income households who for economic reasons cannot be covered by the activities of formal banks and financial institutions (Mwakajuilo, 2011). SACCO performs three 
International Journal of Agriculture and Environmental Research

ISSN: 2455-6939

Volume: 06, Issue: 01 "January-February 2020"

major functions in relations to its members and general economic development of the country. These functions are collecting savings, giving credit and giving financial and non- financial advice to its members in order to facilitate and ensure that SACCO members utilize the micro credit they have borrowed from SACCO.

In some cases, some government and private institutions may also give financial assistance to SACCO in order to enable them give micro credit to their members (Mwakajumilo, 2011). He further posited that the different activities done by households in both urban and rural areas also mean the existence of different SACCO with the aim of assisting the Government to reduce high level of poverty and income inequality in the society.

Unemployment breeds a lot of private and social consequences which are negative (Alam, Khalifa, and Shahjamal, 2009; Alam, 2009). These include poverty, crime, social inequality, loss of output, family disintegration, among others. Governments all over the world make concerted efforts to mitigate these problems (Alam, 2009). In Nigeria several efforts have been made to create jobs for the teaming able bodied people who are available for work but who are yet to find jobs (Goodluck, 2011). One key source of unemployment in Nigeria is dearth of capital required to combine with other factors of production, which are land, labor and entrepreneurship (Nieman, Hough, and Niewenhuizen, 2003). Although growth is critical for poverty reduction, focus on growth alone is not enough (Almas, 2013). Micro-lending has been considered as the latest panacea for poverty alleviation (Magbagbeola, Adetoso, and Owolabi, 2010). Cooperative societies all over the world have been seen as one of the ways of reaching out to the un-banked and the neglected in the society and not a few have come to see it as an alternative to the regular banking, since it, in most case provides members of the group with the financial incentives without the rigors usually experienced in banking halls (Adewakun, 2012). Traditional cooperatives are common throughout Nigeria, but these groups tend to be small, with a common bond based on membership of a kinship, societal and low professional group (Adewakun, 2012). Saving and credit cooperatives Societies are known to provide funding to their members at reasonable interest rate and without requirement of collateral. They are therefore vital organs for financing food crop production (Mavimbela, Masuku, and Belete, 2010).

\section{OBJECTIVES}

i. To examine the effect of credit on the annual farm income of beneficiaries and nonbeneficiaries of SACCO credit;

ii. To determine the factors influencing the participation and intensity of participation in SACCO; and

iii. To identify the constraints faced by beneficiaries and non-beneficiaries of SACCO credit in poverty reduction in the study areas. 
International Journal of Agriculture and Environmental Research

ISSN: 2455-6939

Volume: 06, Issue: 01 "January-February 2020"

\section{STATEMENT OF HYPOTHESIS}

There is no significant difference between the per capita annual farm income of beneficiaries and non-beneficiaries of SACCO Credit

\section{METHODOLOGY}

\section{Study Area}

Benue State, the State lies between Latitudes $6^{0} 25^{\prime} \mathrm{N}$ and $8^{0} 8^{\prime} \mathrm{N}$ of the equator and Longitudes $7^{0} 47^{\prime}$ and $10^{\circ} \mathrm{E}$. (Ministry of land and survey, 2016). It has a total land-area of about 33,955 square kilometers with a population of 4,253,641 (NPC, 2006), with an average population density of 99 persons per square kilometer. The State is blessed with a great loamy soil for agricultural activities. It is one of the 36 states of Nigeria, It comprises 23 Local Government Areas (LGAs) grouped into 3 agricultural zones; A, B, C, respectively. The major food crops produced are yam, rice, cassava, maize, soybean, sesame, cowpea and groundnut at subsistence level. At the end of 2011, the poverty rate of Benue State was estimated at $31.9 \%$ (National Bureau of Statistics, 2012). Meanwhile at the end of 2015 the poverty rate of Benue State was estimated to be $59.2 \%$ based on data collected between 2004 and 2014 (Multidimensional Poverty Index, 2015) published by the United Nations.

There are areas of low population density such as Guma, Gwer East, Ohimini, Katsina-ala, Apa, Logo, and Agatu, each with less than seventy persons per square kilometers, while Vandeikya, Okpokwu, Ogbadibo, Obi, and Gboko have density ranging from 140 persons to 200 persons per square kilometer. Makurdi LGA has over 380 persons per square kilometers. The study used zones (A, B, C) in the State to ease sample design and research instrument distribution. Zone A had the following Local Government Areas: Katsina- ala, Konshisha, Kwande, Logo, Ukum, Ushongo,Vandeikya. Zone B comprises Buruku, Gboko, Guma, Gwer- West, Gwer and Makurdi LGAs. Lastly Zone C comprises Agatu, Apa, Obi, Oju, Ogbadibo, Okpokwu, Otukpo LGAs.

\section{Population and Sampling Procedures}

Three Local Government Areas where rice cultivation was considerably high were selected, each from an agricultural zone in the State. The questionnaire was distributed to few active rice cooperatives whose major focus was solely on rice farming. The active rice cooperatives are distributed in the three LGAs viz; 9 in Katsina Ala, 82 in Makurdi and 10 in Agatu respectively. From these we have the following population for each LGA who are active with members participation measured by their contributions; Katsina Ala- 423 cooperators, Makurdi- 621 
cooperators and Agatu- 167 cooperators Desk officer rice cooperative societies BSMANR, (2017). From the cooperatives actively participating in rice farming, few cooperatives that were accessible filled the questionnaire distributed, the following sample frame were taken: Katsina Ala with 80 registered member rice farmers, Makurdi with 123 registered member rice farmers and Agatu with 63 registered member rice farmers all with beneficiaries and non beneficiaries inclusive respectively. A random sampling technique was used to select respondents for this study. The first stage was done by the selection of these three (3) local government areas because of the availability of more members of Savings and Credit Cooperative (SACCO) with documented records among the three agricultural zones of the state. At the end of the questionnaire administration, out of the 236 questionnaire administered, 208 were correctly filled and returned. Therefore the analysis was based on 208 completed rice farmers data collected. 128 of the beneficiaries and 80 of the non beneficiaries of SACCO credit made up the 208 completed questionnaires.

\section{Data Collection and Analysis}

Primary data was used for this study. These were collected with the aid of structured questionnaire. Data was collected from 236 rice farmers using a structured questionnaire. Out of the 236 questionnaire 208 were retrieved correctly completed. Information collected include: the demographic details of beneficiaries and non-beneficiaries of SACCO credit. Double difference estimator was used to analyze the effect of credit on the poverty level or income of beneficiaries and non - beneficiaries of SACCO Credit. Logistic regression analysis was adopted to determine the factors that influence the level of participation of members in saving and credit cooperatives. Amount of contribution by members of savings and credit cooperative societies was used here as proxy for the level of participation of members in saving and credit cooperatives. Descriptive statistics was used to describe the level of constraint of beneficiaries of the SACCO credit in the study area.

\section{Double difference estimate}

This was used to achieve objective (iv) that is to analyze the effect of credit on the poverty level of beneficiaries and non - beneficiaries of SACCO Credit. Per capita annual farm income stood as a proxy for Poverty Status.

The model is specified as:

$\mathrm{DDE}=\left[\left(\frac{1}{p} \sum_{i}^{p}\left(\bar{Y}_{t i a}-\bar{Y}_{t i b}\right)\right)-\left(\frac{1}{c} \sum_{j}^{c}\left(\bar{Y}_{o j a}-\bar{Y}_{o j b}\right)\right)\right]$

Where: 
$\bar{Y}_{f i a}-\bar{Y}_{f i b}=$ difference of per capita annual farm income for beneficiaries after and before obtaining credit respectively

$\bar{Y}_{o j a}-\bar{Y}_{o j b}=$ difference of per capita annual farm income for non-beneficiaries after and before obtaining credit respectively

$\mathrm{P}=$ number of beneficiaries

$\mathrm{C}=$ number of non- beneficiaries

DDE $=$ the difference between the mean changes in per capita annual farm income for beneficiaries and non- beneficiaries.

\section{Logistic Regression Model}

This helped to achieve objective (v) that is to determine the factors that influence the level of participation of members in saving and credit cooperatives.

Amount of contribution by members of savings and credit cooperative societies was used here as proxy for the level of participation of members in saving and credit cooperatives.

The regression model specification is:

$\mathrm{Y}=\beta_{0}+\beta_{1} \mathrm{X}_{1}+\beta_{2} \mathrm{X}_{2}+\beta_{3} \mathrm{X}_{3}+\beta_{4} \mathrm{X}_{4}+\beta_{5} \mathrm{X}_{5}+\beta_{6} \mathrm{X}_{6}+\beta_{7} \mathrm{X}_{7}++\mathrm{u} \ldots \ldots$. (xi)

Where

$\mathrm{Y}_{\mathrm{i}}=$ Amount of contribution by members (Naira)

$\mathrm{X}_{1}=$ Age $($ years $)$

$\mathrm{X}_{2}=\operatorname{sex}($ Male $=1$, Female $=0)$

$\mathrm{X}_{3}=$ Occupation (farming $=1$ non- farming $=0$ ).

$\mathrm{X}_{4}=$ Household Size (Number of persons)

$\mathrm{X}_{5}=$ Education (years of schooling)

$\mathrm{X}_{6}=$ Total Farm Income (Naira)

$\mathrm{X}_{7}=$ Total Non - Farm Income (Naira)

$\beta_{\mathrm{i}}=$ the coefficients for the respective variables 


\section{Variable specification}

1. Amount of contribution(Y): this served as proxy for the level of participation of members in savings and credit cooperative societies as the dependent variable. This is the amount of money contributed by members of savings and credit cooperative societies on monthly basis.

2. Age $\left(\mathbf{X}_{1}\right)$ : This is the age of the household head in years. An inverse relationship is expected between the age and the level of participation of members in savings and credit cooperative societies. It is expected that as farmers grow older they reduce farming activities due to the energy involve in carrying out farm activities.

3. Sex $\left(\mathbf{X}_{2}\right)$ : The sex of the respondents is included in the model. A direct relationship is expected between sex and the level of participation of members in savings and credit cooperative societies.

4. Secondary occupation $\left(\mathbf{X}_{3}\right)$ : this is the economic activities engaged by farmers apart from farming noted as non farming activities. These include trading, artisans, fishing and civil servant. This variable is expected to have a positive relationship between income and participation of members in the cooperative.

5. Household size $\left(\mathbf{X}_{6}\right)$ :thisis the total numbers in the household of the farmer (wives, children, and other dependents) living in a household at the time of investigation. A direct relationship is expected between the household size and the level of participation of members in savings and credit cooperatives.

6. Educational level $\left(\mathbf{X}_{7}\right)$ : This is the number of years that the household head had spent in formal school, which will be stated as primary education, secondary education and tertiary education. A direct relationship is expected between the savings and credit cooperatives.

7. Income ( $\mathbf{X}_{6}$ and $\mathbf{X}_{8}$ ): This is the income (both farm and non-farm) according to the respondents over a period. A direct relationship is expected between the income (both farm and non- farm) and the level of participation of members in credit cooperatives.

8. Interest rate $\left(\mathbf{X}_{8}\right)$ : this is the amount of interest charged on the credit, measured in naira. An inverse relationship is expected between the interest rate charged on credit and the 
level of participation of members in savings and credit cooperatives. It is removed since it is zero for the non beneficiaries.

\section{Test of difference}

Independent sample t-test was used in testing the two hypotheses for this study. That is use of credit has no significant effect on crop output and there is no significant difference between per capita annual farm income of beneficiaries and non-beneficiaries of SACCO Credit. The per capita annual farm income is to be used as proxy for poverty status. It is intended to be used for before-and-after observations on the same subjects.

The model is specified as follows:

$\mathrm{t}=\frac{\bar{X}_{1}-\bar{X}_{2}}{\sqrt{\frac{s_{1}^{2}}{n}}+\frac{s_{2}^{2}}{n}}$

$\bar{X}_{1}=$ mean crop output of beneficiaries of SACCO Credit

$\bar{X}_{2}=$ mean crop output of non- beneficiaries of SACCO Credit

$\mathrm{S}_{1}{ }^{2}=$ variance crop output of beneficiaries of SACCO Credit

$\mathrm{S}_{2}{ }^{2}=$ variance crop output of non- beneficiaries of SACCO Credit

$\mathrm{n}=$ number of selected members of beneficiaries of SACCO Credit

$\mathrm{n}=$ number of selected members of non- beneficiaries of SACCO Credit.

$\bar{X}_{1}=$ mean per capita annual farm income of beneficiaries of SACCO Credit

$\bar{X}_{2}=$ mean per capita annual farm income of non- beneficiaries of SACCOS Credit

$\mathrm{S}_{1}{ }^{2}=$ variance of per capita annual farm income of beneficiaries of SACCO Credit

$\mathrm{S}_{2}{ }^{2}=$ variance of per capita annual farm income of non- beneficiaries of SACCO Credit

$\mathrm{n}=$ number of selected members of beneficiaries of SACCO Credit

$\mathrm{n}=$ number of selected members of non- beneficiaries of SACCO Credit.

\section{RESULT AND DISCUSSION}


International Journal of Agriculture and Environmental Research

ISSN: 2455-6939

Volume: 06, Issue: 01 "January-February 2020"

\section{Effect of credit on the annual farm income of the respondents}

Table 1.0 presented the Double Difference estimates of the effect of credit on poverty status of the respondents in the study area. The average farm income was used as proxy for the poverty status of the beneficiaries and non beneficiaries of credit. The difference in annual farm income of beneficiaries before and after obtaining credit was estimated as $\$ 29281.74$ and $\$ 51667.31$ respectively. The first single difference of the per capita annual farm income after and before obtaining credit is 22385.57 for the beneficiaries of SACCO credit. The non beneficiaries had $\$ 38991.39$ and $\$ 56657.10$ as the per capita annual farm income difference for before and after credit. The value of the second single difference of the per capita annual farm income for after and before credit is $\$ 17665.71$ for the non beneficiaries. The difference between the two per capita annual farm incomes which is the single differences of the beneficiaries and the non beneficiaries is ( $22385.57-17665.71)$ is 14719.86 . As stated in the model specifican; a positive double difference estimate of per capita annual farm income value for beneficiaries and non beneficiaries before and after obtaining SACCO credit indicates a positive effect of credit on the poverty status of the beneficiaries in the study area. The positive value of the double difference indicates an increase in the per capita annual farm income of the beneficiaries of the SACCO credit. The implication is that credit had positive effect on the per capita annual farm income of beneficiaries of credit Nkonya et al., (2008).

\section{Table 1: Double Difference Estimates of the Effect of SACOO credit on poverty status of beneficiaries and non beneficiaries}

\begin{tabular}{lccc}
\hline Group & \multicolumn{2}{c}{ per capita annual farm income } \\
\hline & Before (N) & After ( $\mathbf{~}$ & Difference \\
Beneficiaries & 29281.74 & 51667.31 & 22385.57 \\
Non Beneficiaries & 38991.39 & 56657.10 & 17665.71 \\
Group difference & 9709.65 & 4989.79 & 4719.86 \\
\hline
\end{tabular}

Source: Field survey 2017

The test of hypothesis carried on the per capita annual farm income of beneficiaries and non beneficiaries before and after obtaining credit showed that the value of the difference between the per capita annual farm income of beneficiaries has a positive value 4719.86 therefore indicates that beneficiaries of credit had more positive increase in per capita annual farm income than the non beneficiaries of credit. The F-value is 14.413 is positive and significant at one percent $(1 \%)$ indicating that all the management variables put together had effect on the per capita annual farm income of beneficiaries of credit. The use of credit therefore, makes a difference in the level of per capita annual farm income of beneficiaries as compared to non beneficiaries. Since there is a significant difference in the per capita annual farm income of 
International Journal of Agriculture and Environmental Research

ISSN: 2455-6939

Volume: 06, Issue: 01 "January-February 2020"

beneficiaries compared to non beneficiaries, the null hypothesis which states that there is no significant difference between the per capita annual farm income of beneficiaries and non beneficiaries of SACCO credit was rejected.

\section{Factors influencing Participation in Savings and Credit Cooperative}

Farm credit has been, over the years, recognized as one of the major input for reviving the agricultural sector in Nigeria (CBN, 2005). This is obvious because it increases the level of productivity, farm profit, and efficiency, this enhances standard of living in the rural areas (Abu, Odoemenem \& Ocholi, 2011). Therefore, farm credit is one of the crucial inputs considered fundamental in agricultural production (Omonona et al., 2010). Majorly, it has been perceived that it is the need for credit and easy access to this credit that motivates participation in the SACCO by farmers. The factors that influence participation of farmers in the SACCO are determined using the amount of contribution by members as proxy. This is because the cooperative believes that all committed and registered active members must be involve in the monthly contribution otherwise seen as non members. The factors influencing participation is presented in table 2.0.

The model was statistically significant at 5 percent level of significant, a positive $\mathrm{R}$ square value of 0.513. This implies that a joint effect of most of the variables influences the participation of members in SACCO. The nine (9) variables were included in the regression model had positive coefficients. The variables sex, education and household size were found to be statistically significant at 5 percent and 1 percent level of significance respectively.

The positive significant coefficient on sex indicates that male sex has higher probability of participating in SACCO programme than being female. As included in the model, the sex from the a priori expectation which was stated to have a direct relationship with the level of participation is true with a positive value and significant at 5 percent.

The household size had a positive significant coefficient indicating that higher number of persons in the household increases the probability of participation in SACCO than lower number of persons in the household. The pursuit for assistance to take care of the members of the household makes the farmer seek and take credit from the cooperative as a source of support to farm income. The positive household size value is statistically significant at 1 percent and conforms to the a priori expectation that a direct relationship is expected between the household size and the level of participation of members in savings and credit cooperative. It indicates that the household size had an influence on the level of participation of members in SACCO NBS (2007). 
According to Elsie (2006); and Sivaram (2000) the level of education plays a significant role in the participation of members in SACCO. The level of education is statistically significant at 1 percent. This agrees with the finding from the positive value of the educational status and show a direct relationship with the level of participation of respondents in SACCO as stated in the a priori expectation. It shows that the level of education determines the level of awareness on the importance of participating in cooperatives.

The household income is positive, therefore plays a significant role in farmers participation in the SACCO. These can be seen in two different ways; from the interaction with cooperators, majority of them belong to the cooperative for them to save in a form of contribution to the cooperative by saving proceeds from their rising farm income which is in turn seen as their shares. Contribution of members is a criterion for commitment to their participation. Why others participate as a means to improve their per capita annual farm income by benefiting from the SACCO credit. Thus the result conforms to the a priori expectation of a direct relationship between the income and level of participation of members in credit cooperatives.

It was found that the coefficient of the non farm income had a positive value and conforms to the a priori expectation. Farmers who engage in other occupation have other source of income; this encourages more tendencies to save. The participation level of those with other source of income order than farm income help them to save the rising income from farming and other secondary source.

The coefficient of age is positive, indicating a direct relationship between age of respondents and their participation in the credit cooperatives. This implies that as they grow older, they participate in the cooperative more due to either the need to get support in terms of credit or to save rising income generated from farming or other non-farm activities. But the result is contrary to the a priori expectation which states an inverse relationship between the age of members and participation in the credit cooperatives. It is rather in conformity to the finding by Idrisa (2007), Arayesh and Mammi (2010), who reported that educational level, farm and non farm income had positive relationship and significantly influences the level of participation in cooperative societies.

\section{Table 2: Logistics Regression Model of Factors influencing participation of respondents in SACCO}

\begin{tabular}{llll}
\hline Variables & Coefficients & Standard Error & T-Value \\
\hline Constant & 0.476 & 1.290 & 1.610 \\
Sex & $0.813^{*}$ & 0.370 & 2.255 \\
Marital Status & -0.360 & 0.419 & 0.697 \\
Education & $0.138^{* *}$ & 0.559 & 7.148 \\
\hline \hline
\end{tabular}


International Journal of Agriculture and Environmental Research

ISSN: 2455-6939

Volume: 06, Issue: 01 "January-February 2020"

\begin{tabular}{llll}
\hline Household size & $0.719^{* *}$ & 0.236 & 5.148 \\
Farming experience & 0.059 & 0.117 & 1.061 \\
Age & 0.293 & 0.230 & 1.341 \\
Occupation & -0.099 & 0.461 & 0.905 \\
Household income & 0.000 & 0.000 & 1.000 \\
H. non-farm income & 0.000 & 0.000 & 1.000 \\
$\mathbf{R}^{2}$ & 0.513 & \\
-2log likelihood & 256.194 & \\
Chi-square & $20.978^{*}$ & \\
\hline (** Significant level at 1\% & significant level at 5\%)
\end{tabular}

Source: field survey 2017

\section{Constraints faced by beneficiaries and non beneficiaries of savings and credit cooperative}

In analyzing the constraints of this study, a likert scale was adopted to test the level of the various limitations caused by the constraints. The result shows that 77.3 percent and 76.2 percent of the beneficiaries and non beneficiaries are faced with poor access to credit as a major (very serious factor) constraint to poverty reduction in the study area.

It was found from the result that 57.8 percent and 61.2 percent beneficiaries and non beneficiaries of the SACCO credit respectively are faced with the constraint of high cost of inputs. This indicated that high cost of input is one of the major constraints (seriously) affecting the level of poverty reduction among the rice farmers in the study area.

In the study it was found that 60.9 percent and 78.8 percent of beneficiaries and non beneficiaries of SACCO credit consider illiteracy level as one of the main constraints (very seriously) to poverty reduction on rice farmers in the study area. This could be because the level of educational exposure gained by members of the SACCO is not efficient enough to help them in innovation adoption. Majority of the members 47 percent and 39 percent of beneficiaries and non beneficiaries respectively from the field survey have only secondary and primary education.

The study result showed that 43 percent and 53 percent of beneficiaries and non beneficiaries of SACCO credit see collateral as one of the major constraints (seriously) affecting the level of poverty reduction among rice farmers in SACCO in the study area. From the survey, it was found that farmers complain of demand for collateral from financial institutions to access credit. In most cases, the conditions and categories of collateral demanded from farmers are beyond the farmers' asset or available facilities.

The result further disclosed that 52.3 percent and 68.8 percent of the beneficiaries and non beneficiaries consider government interference from policies and interventions as one of the 
constraints (not seriously) affecting the members of the SACCO respectively. This could be because the government understands that cooperatives are meant to be voluntarily and democratically run by the members of the organization independent of external leadership and governance.

About 35.2 percent and 51.2 percent of the beneficiaries and non beneficiaries of the SACCO credit consider interest rate as one of the constraints (seriously) affecting the level of poverty reduction among rice farmers in the study area respectively.

Finally the result showed that 39.1 percent and 61.2 percent of the beneficiaries and non beneficiaries consider inadequate capital as a constraint yet (not seriously) affecting the level of poverty eradication of the rice farmers SACCO members in the study area.

The result of the analysis therefore revealed that the constraints faced by the Savings and Credit Cooperatives are affecting the cooperative in different levels. From the severe to less severe problems; these can be seen in table 3.0 with poor access to credit (with mean for beneficiaries and non beneficiaries as 3.711 and 3.750), illiteracy level (3.492 and 3.713), and high cost of inputs (3.195 and 3.388), collateral(it came as the fourth most server for non beneficiaries and fifth most severe for beneficiaries of SACCO credit), interest rate (this is the fourth most severe problem for the beneficiaries and fifth for the non beneficiaries), government interference (2.441 and 1.937 it is also seen as the least of the problems faced by rice farmers cooperators) and inadequate capital (2.680 and 2.363) respectively as the major constraints faced by the SACCO members in the study area. This is listed in the order from most severity to less severe problems. Poor access to credit is ranked as the most server problem faced by both the beneficiaries and non beneficiaries of credit. This is one of the major functions of the Savings and Credit Cooperative, making credit available for members to access via collaboration with other financial outfits or donor agencies.

Table 3: Constraints faced by members of Savings and Credit Cooperative

\begin{tabular}{|c|c|c|c|c|c|c|c|c|}
\hline \multirow[t]{2}{*}{ Constraints } & \multicolumn{3}{|c|}{ Beneficiaries } & \multirow[b]{2}{*}{ Rank } & \multicolumn{4}{|c|}{ Non Beneficiaries } \\
\hline & Freq & $\%$ & Mean & & Freq & $\%$ & Mean & Rank \\
\hline $\begin{array}{lll}\text { Poor access } & \text { to } \\
\text { credit } & & \\
\end{array}$ & 99 & 77.3 & 3.711 & $1 \mathrm{st}$ & 61 & 76.2 & 3.750 & $1^{\text {st }}$ \\
\hline High cost of inputs & 74 & 57.8 & 3.195 & $3 \mathrm{rd}$ & 49 & 61.2 & 3.388 & $3^{\mathrm{rd}}$ \\
\hline Illiteracy level & 78 & 60.9 & 3.492 & 2nd & 63 & 78.8 & 3.713 & $2^{\text {nd }}$ \\
\hline Collateral & 55 & 43.0 & 2.867 & 5 th & 43 & 53.8 & 3.012 & $4^{\text {th }}$ \\
\hline Government interf & 67 & 52.8 & 2.441 & 7 th & 55 & 68.8 & 1.937 & $7^{\text {th }}$ \\
\hline High interest rate & 45 & 35.2 & 2.977 & 4 th & 41 & 51.2 & 2.650 & $5^{\text {th }}$ \\
\hline
\end{tabular}


International Journal of Agriculture and Environmental Research

ISSN: 2455-6939

Volume: 06, Issue: 01 "January-February 2020"

\begin{tabular}{lllllllll}
\hline Inadequate capital & 50 & 39.1 & 2.680 & 6 th & 49 & 61.2 & 2.363 & $6^{\text {th }}$ \\
\hline
\end{tabular}

Ranking is according to the severity of the constraints $1^{\text {st }}$ to $7^{\text {th }}(4=$ Very seriously, $3=$ seriously, $2=$ not seriously and $1=$ not very seriously)

Source: field survey 2017

\section{CONCLUSION}

The analysis revealed that Savings and Credit Cooperatives have helped the member improve their livelihood. It has positively changed members' poverty status by improving per capita annual farm income of beneficiaries of the SACCO credit. Nevertheless, the beneficiaries and non beneficiaries had some factors that limited their efforts towards poverty reduction. These constraints they stated to include poor access to credit, illiteracy level, high cost of inputs and high interest rate charged on credit. This automatically indicated that the members can achieve success in fight against poverty but for these constraints. There is room to the reduction of poverty via the improvement of the per capita annual farm income of the SACCO members in the study area.

\section{RECOMMENDATION}

i. It was revealed that credit had positive effect on out comes by increasing per capita annual farm income of Savings and Credit Cooperative member who are beneficiaries of the credit. SACCO executives and the Government should develop strategies that will bring in more funding; loans and grants to the cooperative consequently enhance availability of credit to members.

ii. The major constraint identified by members of the Savings and Credit Cooperative was poor access to credit. Effort should be made to create awareness to the members of SACCO and other rice farmers in the study area of the availability of formal agricultural credits such as the current anchor borrowers program, Fadama III project etc. for rice production.

iii. Farmers need more education by extension services since illiteracy level among rice famers cooperators is seen as one of the major constraints to high crop output and increase in farm income. With extension services, even the farmers who have no formal education will improve their method of farming by adoption of modern technological innovations.

iv. Farm income and non farm income had positive coefficient and are therefore significant influence to participation in Savings and Credit Cooperative. SACCO members therefore need to indulge in some non -farm activities such as trading, artisan, fishing and even civil service to diversify their income. This will improve 
Volume: 06, Issue: 01 "January-February 2020"

farmers' per capita annual farm income; hence help in poverty reduction in the study area.

\section{REFERENCES}

Adebayo, A. and Yusuf, O.R. (2004). Cooperatives and Poverty Alleviation in Rural Settlement Of Kwara State, Nigeria.

Adewakun, A. (2012), Cooperative as tool for enhancing financial inclusion, African Newspaper of Nigeria. Oct.13,P1.

Ajaero C. (2007). A brand new image for Benue, Newswatch Magazine (Newswatch Communications). July 12,2007 from http://www.wikipedia.com

Akende, S.O. and Akpokodje, G. (2003), Rice Prices and Market Integration in Selected Areas in Nigeria. Agriculture and Rural Development Department Research Report

Albouy, David, 2010. Evaluating the efficiency and equity of federal fiscal equalization, Journal of Public Economics, Elsevier, vol. 96(9-10), pages 824-839.

Alam G.M. (2009). Can governance and regulatory control ensure private Higher education as business or public goods in Bangladash? African Journal Business Management, 3(12), 890-906

Almas H, 2013 The Relationship between Income Inequality and Globalization Retrieved July 7, 2010 from http://www.wider.unu.edu/

Alam G.M., Khalifa. M.T.B and Shahajamal, M.M. (2009). Return from education system in Bangladash: an investigation on comparative flashback scenario. African Journal Business Management, 3(10): 567-575.

Arayesh B., Mammi S., (2010), Identifying the Factors Affecting the Participation of Agricultural Cooperatives' Members., American journal of agriculture and biological sciences 6(4):560-566.

Biyi, D. (2005). Government Policies and Competitiveness of Nigerian Rice Economy Paper represented at the "workshop on Rice Policy and Food Security in sub-Saharan Africa" organized by WADA, Cotonon, Republic of Benin, November 07 - 09, 2005. 
International Journal of Agriculture and Environmental Research

ISSN: 2455-6939

Volume: 06, Issue: 01 "January-February 2020"

Bzugu P.M., M.M.Gwary, and Y.L. Idrisa, (2005).Impact of Extension Services on Rural Poverty Alleviation among Farmers inAskira/Uba Local Government Area of Borno Sate. Shael Analyst, Faculty of Management Sciences, University of Maiduguri. PP96 103. Food Policy, 26, 4

Elisie Y.S.(2006). Gender and women participation in bamboo-based Rural artisanal Industry and its impact on Rural Livelihood A Case Study in Yunnan, China. INBAR, a US-based NGO.

Goodluck, J. (2011). Job creation an urgent task; Punch Newspapers, Feb.24.

Idrisa, Y.L., Sulumbe, I.M. and Mohammed, S.T. (2007), Socio-economic factors affecting the participation of women in agricultural cooperative in Gwoza Local Government, Borno State, Nigeria

Jones, M.P. (1995), the Rice Plant and its Environment West African Rice Development Association (WARDA) training Guide 2. P $1-16$.

Magbagbeola, J.A.O., Adetoso, J.A and Owolabi, O.A. (2010) Neglected and Apicrutilizes Species (NUS):A panacea for community focused development to poverty alleviation/poverty reduction in Nigeria. Journal of Economics and international finance, 2(10):208-211.

Mavinbela, P., Masuku, M.B. and Belete, A. (2010). Contribution of savings and credit cooperatives to crop production in Swaziland: A case study of smallholder farmers. African Journal of Agricultural Research; 5(21):2868-2874.

Mwakajumilo. S.L.I (2011). The Role of Informal Microfinance Institutions in Savings Mobilization, Investment and Poverty Reduction. A Case of Savings and Credit Cooperative Societies (SACCOS in Tanzania From 1961-2008. Unpublished Doctorial Thesis. St Clement University, Turks and Caicos Islands of British West.

Niemen, G., Hough, J. and Niewenhunizen, C. (2003). Entrepreneurship- A South African Perspective. Hatfield, Pretoria: Van Schaik Publishers.

Nkonya, E., Philip, D., Mogues, T., Pender, J., Yahaya, M. Adebowale, G.J and Arokoyo, T. (2008). Impact of a pro-poor community-driven development Project in Nigeria PP 10-36 A report submitted to International food policy research institute on sustainable solutions for ending hunger and poverty. 
Oguntola, S.I (1988). Female-Oriented Technologies in Agricultural Research in Oyo State. Unpublished B.Sc Thesis in the Department of Extension and Rural Development, University of Ibadan, Nigeria

Olorunsanya, E.O (2009). Gender of Household Heads and Relative Poverty among Rural Farming Household in Kwara State An Unpublished PhD Thesis in the Department of Agricultural Economics and Farm Management, University of Illorin, Nigeria

Sivaram, B. (2000). Productivity Improvement and Labor relations in the tea industry in South Asia The International Labor Organization Geneva, Switzerland 